\title{
Environmental pollution as a threats to the ecology and development in Guinea Conakry
}

\section{Zanieczyszczenie środowiska jako zagrożenie dla ekologii i rozwoju w Gwinei Conakry}

*dr inż. Piotr F. Borowski - Wydział Inżynierii Produkcji, Szkoła Główna

Gospodarstwa Wiejskiego w Warszawie, ul. Nowoursynowska 166,

02-787 Warszawa, piotr_borowski@sggw.pl

Keywords: pollution, Guinea, development, poverty

Słowa kluczowe: zanieczyszczenie, Gwinea, rozwój, ubóstwo

\begin{abstract}
The aim of the research was to investigate the relationship between environmental pollution in Guinea Conakry and the levels of development as well as the assessment of climatic conditions as they influence pollution levels. In order to explore economic, social and cultural situations in Guinea, in-depth interviews were conducted and also face-to-face interviews were recorded. There were observations made in two extreme climatic conditions (dry season and rainy season) that have allowed inference to the impact of climatic conditions on pollution levels.
\end{abstract}

() IOŚ-PIB

\section{INTRODUCTION}

The pollutants of the environment, which are a result of human activity, have different meanings and can be understood in different ways depending on the part of the world making the observation. In the highly developed countries, pollution usually signifies $\mathrm{CO}_{2}$ emission or other greenhouse gases, whilst in poor and non-developed countries, for example, Guinea, pollution means garbage of basic human life activity. When in Europe or America the economy is looking for solutions concerning the reduction of environmental impact at a global scale for industry, Guinea cannot cope with littering on the streets, in the rivers, beaches and seaside. The studies were undertaken in Conakry (capital of Guinea - the biggest metropolis in Guinea), in order to investigate links between pollution (ecological and environmental aspects) and economic and socio-cultural situations in this part of Africa. Conakry has a wide range of environmental and public health problems including respiratory illnesses because of elevated levels of air pollution [World Health Organization, 2006a]. Local sources of pollution include unregulated combustion and processing emissions from industrial point sources, unregulated emissions from leaded gasoline vehicles, widespread open pit burning of household and vegetative waste and residential wood burning cooking ovens [Weinstein et al. 2010]. In urban areas, particulate emissions and gaseous air pollutants include, first of all, anthropogenic emissions from the municipal, transport sector and industry. The impact of harmful substances is conducive

\section{Streszczenie}

Celem badań było przeanalizowanie związku między zanieczyszczeniem środowiska w Gwinei Konakry a poziomem rozwoju oraz dokonanie oceny wpływu warunków klimatycznych na poziom zanieczyszczeń. W celu zbadania sytuacji gospodarczej, społecznej i kulturalnej w Gwinei przeprowadzono wywiady pogłębione, a także bezpośrednią rozmowę, natomiast obserwacje wykonane w dwóch ekstremalnych warunkach klimatycznych (pora deszczowa i pora deszczowa) pozwoliły wywnioskować wpływ warunków klimatycznych na poziom zanieczyszczeń.

to the growth of morbidity of city populations and can lead to increased mortality [Sówka et al. 2016].

The main hypotheses $(\mathrm{Hm})$ posed in the research were concerned with the relationships that occur between pollution and socio-economic situation. Hypothesis $\mathrm{Hm} 1$ indicated on links between levels of economic development and levels of pollution, hypothesis $\mathrm{Hm} 2$ indicated on links between social-cultural mentality of people and level of pollution. Auxiliary hypothesis (Ha) was related to the weather conditions. Hypothesis $\mathrm{Ha}$ was concerned with the level of pollution in two kinds of weather: dry and wet season. The great value of the research was realised in the in-depth interviews with the highest representatives of the government and the President of Guinea.

\section{THE STATE OF GUINEA'S ENVIRONMENT}

Pollution of the soil, groundwater, surface water and coastal zones from chemicals and human activity is a substantial threat to Guinea's natural environment and the health condition of its citizens. Overcrowded urban environment affects deforestation, desertification and other irrevocable ecological changes [Xu, Binyet. 2017]. Construction of new housing is also a key problem that might cause a rapid degradation of the area if rational management and proper, informed planning is not initiated [Sylla et al. 2012]. In towns and urban areas, rivers, streams 
and watercourses become disposal sites for human and solid wastes, putting the populations at greater risk from water-borne diseases (such as the cholera crisis in Conakry in August 2012) and polluting the environment at large. According to some previous researches [Gelinas et al. 1996], widespread well water contamination for nitrate and faecal bacteria was found throughout districts of Conakry. In order to increase the access to the clean water, the management of the potable water supply in cities and a reform aimed the extending the water network should be continuously realised [Bah, Morin, Diallo 2009]. The pollution of environment has also increased because of the diseases that can be transmitted between people through direct contact with blood and other body fluids of patients and those who die from it (such as an epidemic of Ebola virus disease in Guinea represents the first ever outbreak of Ebola in a West African country in 2013). With the rainy season, much of this waste is flushed to the ocean contaminating the shoreline, jeopardising marine and coastal flora and fauna and adding greater strain on the livelihoods of many of Guinea's citizens. The pollution in Guinea also comes from the mining industry. The mining industry of Guinea was developed during colonial rule; the minerals extracted consisted of iron, gold, diamond and bauxite. Dangerous chemicals routinely used in gold mining (e.g. mercury and cyanide for gold recovery) remain uncontrolled in their use, storage and disposal. The bauxite industry's use of caustic soda for alumina production follows established standards and norms, but the potential for hazardous spills will increase as it aims for greater production. Moreover, the recent presidential directives to increase agricultural production advocate greater use of fertilisers and pesticides without forethought about controlling their use and means to mitigate their impact on the environment and human health. The same is true for the greater use of petroleum products and other chemicals that will increase substantially with increased mining activity. No guidelines are in place to mitigate spills of mining and agricultural chemicals or toxic waste material [Guinea Environmental Threats... 2012]. In Guinea, some Legal Acts concerning environmental issue exist, but the using of the documents is on the very low level. One of the most important documents is Environmental protection law [Code de la protection et de la mise en valeur de l'environnement, Ordonnances N045/ PRG/87 et N022/PRG/89]. This law seeks to combine protection of the environment with sustainable development of natural resources (Articles 1 and 5). Those articles say that the purpose of this Code is to establish the fundamental principles for managing and protecting the environment against all forms of degradation in order to protect and exploit the exploitation of natural resources, to combat various pollution and nuisances and to improve conditions of life of the citizen, whilst respecting the balance of his or her relations with the surrounding environment. At a level of generality that includes the entire 'environment' (defined as all natural and artificial elements engaged in interaction with the activities of humans and all living organisms - Article 2), property rights are shared at two levels: national and international, 'the Guinean environment constitutes a national patrimony which is an integral part of the universal patrimony' (Article 4). Its conservation, the maintenance of its human resources, the prevention or limitation of activities liable to degrade or harm the health of persons and their property are of general interest [Property Rights...2008].

But the main problem is that the legal rules are not implemented into real life. The Natural Resources Management statutory environment in Guinea is segmented and confusing [Property Righs...2008]. Current natural resource legislation in Guinea is spread across several sectors including land, forests, water and minerals. The natural resources 'codes' often lack adequate application texts and are often little known to the general population and even to some of the technical agents responsible for its implementation. As a confirmation of the observation made by author in Guinea, there is a report by World Health Organization (WHO) that indicate situation in poor countries of the West Africa. According to the latest urban air quality database [WHO 2016], $98 \%$ of cities in low- and middle-income countries with more than 100,000 inhabitants do not meet WHO air quality guidelines. In this group of the cities, there is also Conakry. Pollution, dirt, stench and bad environmental conditions are visible in the capital of Guinea. Items mentioned earlier are shown in Table 1.

Table 1. Pollution in Guinea by numbeo. ${ }^{1}$

\begin{tabular}{|c|c|c|}
\hline Rated item & \multicolumn{2}{|c|}{$\begin{array}{c}\text { Size of the } \\
\text { indicator }\end{array}$} \\
\hline $\begin{array}{c}\text { Air pollution } \\
\text { Drinking water pollution and } \\
\text { inaccessibility }\end{array}$ & 100.00 & Very high \\
\hline Dissatisfaction with garbage disposal & 87.50 & Very high \\
\hline Dirty and untidy & 100.00 & Very high \\
\hline Noise and light pollution & 68.75 & Hery high \\
\hline Water pollution & 93.75 & Very high \\
\hline Dissatisfaction to spend time in the city & 93.75 & Very high \\
\hline Dissatisfaction with green and parks in & 87.50 & Very high \\
\hline the city & & \\
\hline
\end{tabular}

Source:

https://www.numbeo.com/pollution/country_result.jsp?country=Guinea.

Owing to the growing problem of the impact of air pollution on natural ecosystems, it is necessary to continue to monitor developments and long-term trends in air pollution and chemical precipitation in different types of ecosystems [Pokryvkowa et al. 2016].

\section{MATERIALS AND METHODS}

\subsection{Study area}

The study covers about $40 \mathrm{~km}$ of seaside of Conakry with tributaries of rivers and canals. During the research, the interviews and observations were realised in the congested areas in the capital

${ }^{1}$ Numbeo is the world's largest database of user-contributed data about cities and countries worldwide. Numbeo provides current and timely information on world living conditions including cost of living, housing indicators, health care, traffic, crime and pollution. To generate a current index (which is always updated), numbeo use data up to 36 months old. For pollution section, they include some relevant data from the WHO and other institutions if they find it helpful. 

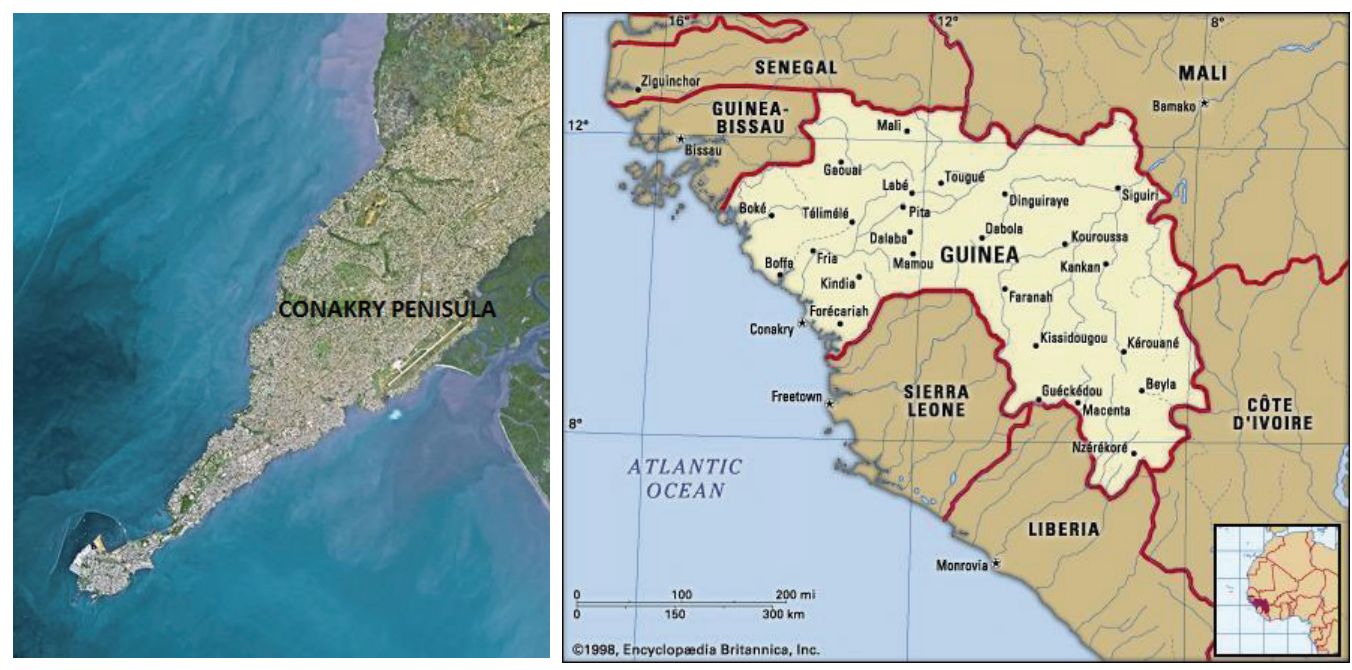

Figure 1. Location of 'Conakry Peninsula' on the Map (source: www.britannica.com/place/Guinea).

Table 2. Kind of research concerning hypotheses.

\begin{tabular}{|c|c|c|c|c|}
\hline & & Hypothesis Hm1 & Hypothesis Hm2 & Hypothesis Ha \\
\hline \multirow{2}{*}{ Qualitative } & Observation & $\mathrm{x}$ & $\mathrm{x}$ & $\mathrm{x}$ \\
\hline & Primary research & $\mathrm{x}$ & $\mathrm{x}$ & $\mathrm{x}$ \\
\hline
\end{tabular}

Sources: Author's own elaboration.

of Guinea. Conakry is located on the peninsula ${ }^{2}$ and consists of slums, buildings and villas located together in the same area. According to Köppen-Geiger classification, Conakry has an equatorial tropical monsoonal climate $(\mathrm{Am})$ with a dry season and a heavy monsoon the rest of year, no cold season [Köppen, Geiger 1936]. The Holdridge life zones system ${ }^{3}$ situates Conakry in or near the tropical wet forest biome [Holdridge 1947].

Qualitative market research methods that include focus group studies, depth interviews and observational techniques [Belk 2008] were realised. In this study, the following market research methods were used: (1) observation, (2) primary research and (3) secondary research [Creswell 2009]. Author carried out the series of research listed above on site in Guinea. Observations and primary research were realised directly within April-May and August-September 2015, whereas desk research were realised as on-going study. Table 2 indicates the area of research covered by qualitative and quantitative methods.

The in-depth interview method can produce very precise and specific answers as well as an exhaustive and varied knowledge about individual determined experiences, opinions and motives. The method of the in-depth interview was appropriate because the subject and issue of the research were in the nature of something controversial, sensitive for behavioural activity of society. To investigate the characteristic features of an environment through in-depth research that explores the background and context for decision making in the strategy development of environmental

${ }^{2}$ Conakry lies on Tombo (Tumbo) Island and the Camayenne (Kaloum) Peninsula. ${ }^{3}$ The Holdridge life zones system is a global bioclimatic scheme for the classification of land areas. protection, the qualitative research was applied. Qualitative research methods were designed in this study to talk to a relatively few respondents but from all social group of Guinea in the target audience of interest: Minister of President, Director and Diligent man from Hydrology Institute, businessman from private sector, high school student. In-depth Interviews were realised in Conakry in order to examine the cause of this situation and find confirmation or denial of hypothesis.

\subsection{Main hypothesis}

The main hypothesis $\mathrm{Hm}$ that concerns the relations and linkage between economic and social-cultural situations was examined. In order to explore ecological market in Guinea, the in-depth interviews, as well as the face-to-face interviews, discussions and conversations with the representatives of local population, were conducted. A more detailed survey on solid pollution, which combined questionnaires and on-site investigations, was aimed at obtaining knowledge of processes, types and quantities of wastes and approaches to trash. It was the first research in which representatives of various social groups participated, starting from the ruling class - Presidential Minister, Minister from the government - by the employees of state institutions to students. In order to show the relation between elements mentioned earlier, the numerical values that allow to calculate the Pearson correlation have been assigned. ${ }^{4}$ At the beginning, the weight (importance) of a job position has been assigned from 5 to 1 .

${ }^{4}$ The Pearson correlation is a measure of the linear correlation between two variables $X$ and $Y$. 
Table 3. Weights and ratings of indicated items.

\begin{tabular}{|c|c|c|c|c|}
\hline Job Position & $\begin{array}{c}\text { Weight of a job } \\
\text { position }\end{array}$ & $\begin{array}{c}\text { Value of economic } \\
\text { condition }\end{array}$ & $\begin{array}{c}\text { Value of social } \\
\text { condition }\end{array}$ & $\begin{array}{c}\text { Economic and } \\
\text { social together }\end{array}$ \\
\hline Minister & 5 & 5 & 3 & 8 \\
\hline Minister & 5 & 4 & 3 & 7 \\
\hline Director & 4 & 3 & 3 & 6 \\
\hline Businessman & 4 & 2 & 2 & 4 \\
\hline Clark & 3 & 1 & 1 & 2 \\
\hline Student of university & 2 & 1 & 1 & 2 \\
\hline Student of high school & 1 & 1 & 1 & 2 \\
\hline
\end{tabular}

Source: author's own research.

Table 4. Precipitation and number of wet days in Conakry.

\begin{tabular}{|c|c|c|c|c|c|c|c|c|c|c|c|c|}
\hline & Jan & Feb & Mar & Apr & May & Jun & Jul & Aug & Sep & Oct & Nov & Dec \\
\hline $\begin{array}{c}\text { Average } \\
\text { Precipitation } \\
(\mathrm{mm})\end{array}$ & 1 & 1 & 3 & 22 & 137 & 396 & 1130 & 1104 & 617 & 295 & 70 & 8 \\
\hline $\begin{array}{l}\text { Number of Wet } \\
\text { days (probability } \\
\text { of rain on a day) }\end{array}$ & $\begin{array}{c}0.5 \\
(2 \%)\end{array}$ & $\begin{array}{c}0.5 \\
(2 \%)\end{array}$ & $\begin{array}{c}2 \\
(6 \%)\end{array}$ & $\begin{array}{c}3 \\
(10 \%)\end{array}$ & $\begin{array}{c}13 \\
(42 \%)\end{array}$ & $\begin{array}{c}24 \\
(80 \%)\end{array}$ & $\begin{array}{c}29 \\
(94 \%)\end{array}$ & $\begin{array}{c}29 \\
(94 \%)\end{array}$ & $\begin{array}{c}26 \\
(87 \%)\end{array}$ & $\begin{array}{c}21 \\
(68 \%)\end{array}$ & $\begin{array}{c}10 \\
(33 \%)\end{array}$ & $\begin{array}{c}3 \\
(10 \%)\end{array}$ \\
\hline
\end{tabular}

Source: http://www.conakry.climatemps.com/precipitation.php.

For the most important job position - Minister in the government, Presidential Minister - the weight has been given as 5 . For the lowest position - student in the high school - the weight has been assigned as 1. Value of the economic and social condition, from 1 to 5 , was given to each group of respondents. The highest condition received value 5 ; the lowest condition received value 1. All weights and values have been assigned by author of the research as a result of the in-depth interview and are summarised in Table 3.

Pearson correlation between job position and economic condition: 0.86 .

Pearson correlation between job position and social condition: 0.88 .

Pearson correlation between job position and both (economic and social): 0.88 .

We can observe high positive correlation between job position and economic and social conditions, which indicates that poverty and low level of life translate into possibility of achieving a professional position and the higher level of the job position allows to increase the higher condition of the life.

\subsection{Auxiliary hypothesis}

The auxiliary hypothesis $\mathrm{Ha}$ states that heavy rainfall is accelerating the movement of trash and different waste into the seaside. The observation studies were conducted in April-May 2015 and August-September 2015 in Conakry. The periods of the research were chosen according to the weather condition. Average annual rainfall in Guinea Cost region is more than 3,000 $\mathrm{mm}$ per year, but in particular months precipitation are from 1 $\mathrm{mm}$ in January to $1,130 \mathrm{~mm}$ in July. Average rainfall for Conakry (by months) is shown in Table 4. According to Platts, Omeny and Marchant (2015), rainfall is projected to increase in western and eastern parts of the continent, coupled with increased seasonality.

Author's own observation confirmed that April-May are the months with dry climate condition, whilst August-September are months with high level of rainfall. In Guinea, similar to other countries where human activity destroyed the environment, we can observe similar phenomena. Owing to the influence of human activities and climate change, and disorderly development and inefficient use of water resources, multiple source rivers have broken away from the main stream one after another, therefore, the water yield from the source rivers into the main stream out of the river source water has been falling [Zhang 2017].

\section{RESULTS AND DISCUSSION}

More people living in urban areas means greater levels of waste generation. With the increase in population, and an increase in the number of people who are moving to urbanised areas, the amount of solid waste produced is increasing. As municipalities cannot cope with this, large quantities of solid wastes are not collected, not treated or not disposed of in designated sanitary landfills. Plastic waste contamination is one of the major issues at present for many countries, especially non-developed countries such as Guinea. The environmental problems that the Guinea face are resulting mostly from the lack of effective coordination and consultation mechanism for environmental management [Ukwe, Ibe 2010]. In Conakry, there are not any waste systems to clear up the apparent plastic from the ocean surface. According to Ukwe et al. (2006), the Global Programme on municipal 


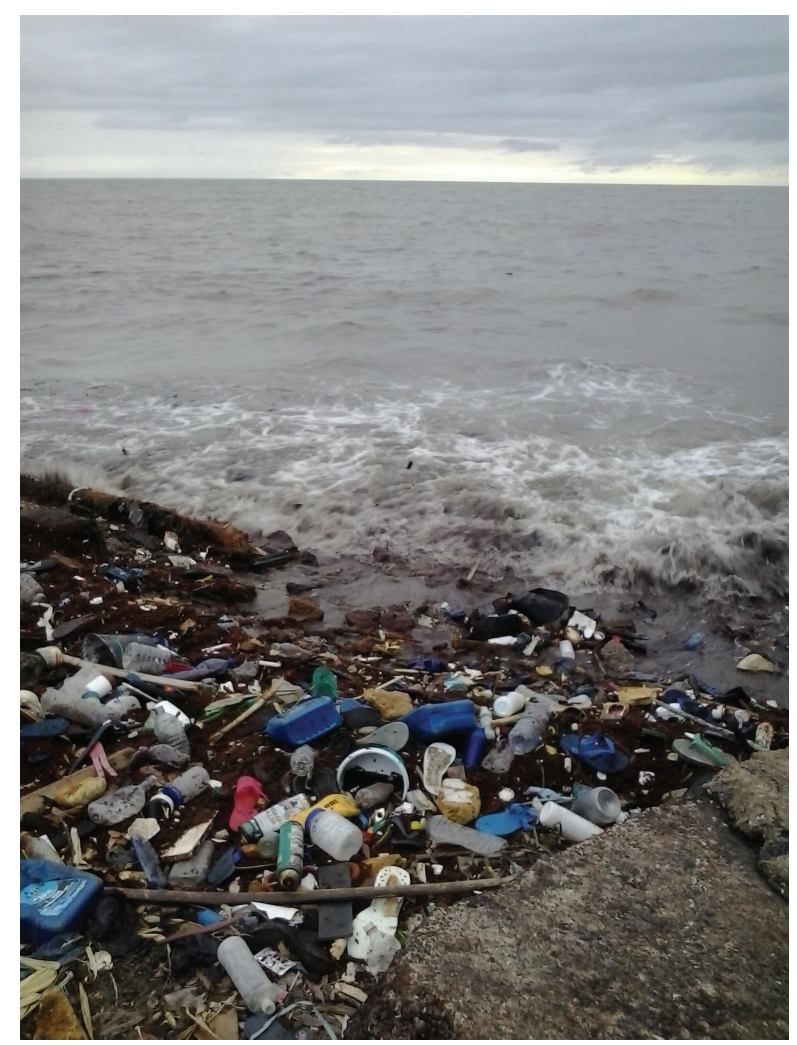

Picture 1. Seaside.

(Pictures 1 and 2 were taken by the author)

wastewater, the physical alteration and destruction of habitats, and nutrients, by actions at all levels should be implemented.

Pollution arising from discharges of domestic and industrial effluents and uncontrolled disposal of solid wastes, especially in the highly industrialised and densely populated cities, is a major threat to Guinea region [Donkor, Abe 2012]. The data of Lourenço research realised in this region strongly suggest that microfibers are spread along the food chain, with birds apparently ingesting microfibers through the ingestion of contaminated prey. This indicates that microfibers are not only accessible to organisms in direct contact with contaminated water or sediment but also to other species that have trophic links with those species, which of course includes human beings [Lourenco 2017]. The problem of diseases of the domestic poultry is also concerned with pollution in the Guinea [Barry, Diaby, Diallo, Thys, Dorny 2009].

As a consequence, large quantities of solid waste are illegally dumped or burned, resulting in increased pollution of the ocean, air and soil (Pictures 1 and 2). It is now widely believed that public participation must be integrated in environmental permitting processes, because it ensures a decision-making process that is generally more open, democratic and transparent [Jiang, He, Hiltunen 2015]. The own observation realised by the author confirms these opinion.

The realised interview showed that persistently poor economic performance has negatively impacted on poverty reduction and

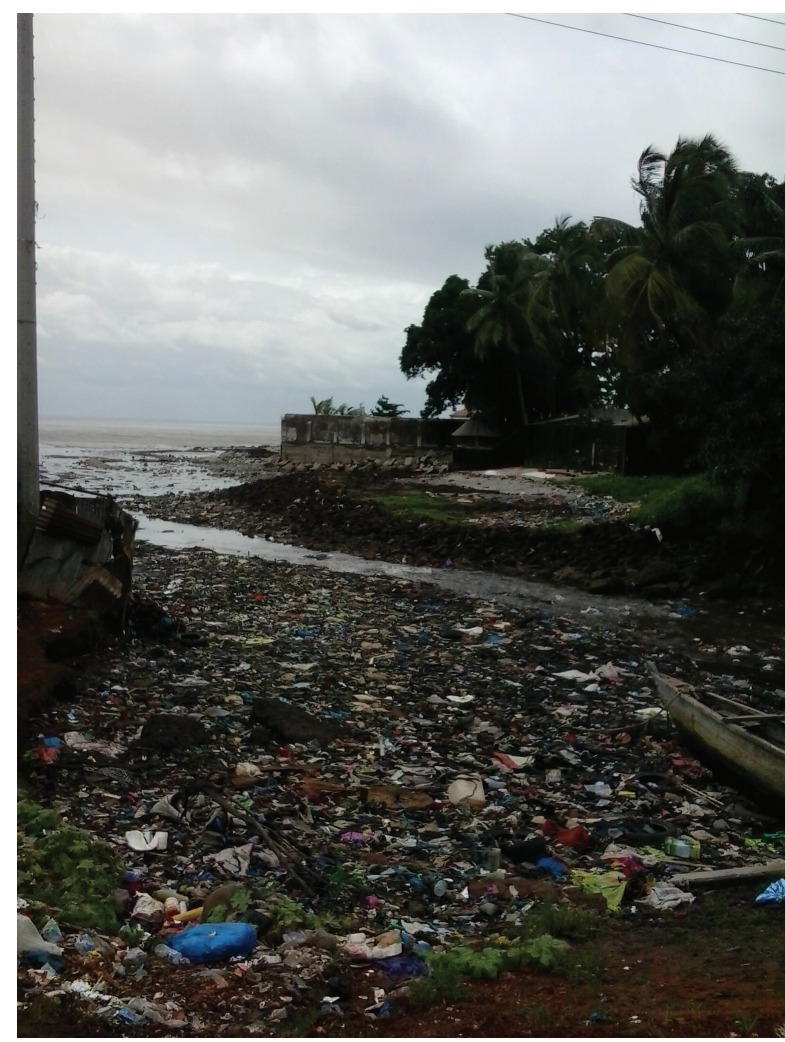

Picture 2. River tributary to the sea.

human development. All respondents indicated that high level of pollution and low human development are results of financial situation. Guinea remains one of the poorest countries in the world and is ranked among the lowest-performing countries as a low human development country in the UNDP Human Development Index (179 of 187 countries surveyed in 2014).

Despite the presence of an exceptional natural endowment, Guinea's economic performance in the past decade has been below expectation, and the country has performed more poorly than many of its neighbours. Relatively poor economic performance is, in part, a consequence of long periods of political instability and weak governance. Corruption in Guinea in 2016 was ranked as 142 of 175 . Poorly equipped schools and elections decided by money are just some of the consequences of public sector corruption. Corruption is a problem for all countries. A poor score is likely a sign of widespread bribery, lack of punishment for corruption and public institutions that don't respond to citizens' needs.

\subsection{Limitation of the research}

The research was realised only in two periods of a year. In order to extrapolate the results of observation on a full year and make generalisations of results, the author should conduct study during the whole year - in every month, in all the seasons 


\section{REFERENCES}

BAH A. K., MORIN R., DIALLO A. (2009). Differentiated domestic water rates and consumption in African cities: the case of Conakry. Canadian Journal of Development Studies, 28(3/4), 415-437.

BARRY A. M., DIABY K., DIALLO B., THYS E., DORNY, P. (2009). A study of parasitic diseases on pre-urban poultry farms of Conakry (Guinea). Bulletin of Animal Health and Production in Africa, 57(1), 93-95.

BELK R.W. (2008), Handbook of Qualitative Research Methods in Marketing (Elgar Original Reference), Edward Elgar Publishing.

Code de la protection et de la mise en valeur de l'environnement, Ordonnances $N^{\circ} 045 / P R G / 87$ et $N^{\circ} 022 / P R G / 89$

Corruption Perception Index 2016, https://www.transparency.org/ news/feature/corruption_perceptions_index_2016

CRESWELL, J.W. (2009), Research Design: Qualitative, Quantitative and Mix Methods Approaches. Sage Publication Inc.

DONKOR S. M., ABE J. (2012). Impact of climate change in the Guinea Current Large Marine Ecosystem region. Large Marine Ecosystems, Frontline observations on climate change and sustainability of large marine ecosystems, vol. 17, 64-80.

Guinea Environmental Threats and Opportunities Assessment, (2012), United States Agency for International Development.

GELINAS Y., RANDALL H., ROBIDOUX L., SCHMIT J. P. (1996), Well water survey in two districts of Conakry (Republic of Guinea), and comparison with the piped city water. Water Research, 30(9), 2017-2026.

HOLDRIDGE L.R., (1947), Determination of World Plant Formations From Simple Climatic Data, Science, Vol. 105, Issue 2727, pp. 367-368.

JIANG L, XIANGLIN H, HILTUNEN E, (2015), Public participation in environmental permitting: the Finnish approach and its effects, Int. J. Environment and Pollution, 57, 1-2: 1-16.

KOPPEN W., GEIGER R. (1936), Das geographische System der Klimate - Handbuch der Klimatologie, Berlin, Verag von Gebruder Borntraeger. p.C16.

LOURENCO P.M., SERRA-GONCALVES C., FERREIRA J.L., CARY, T., GRANDEIRO J.P., 2017, Plastic and other microfibers in sediments, macroinvertebrates and shorebirds from three intertidal wetlands of southern Europe and West Africa, Environmental Pollution, 231: 123-133.

PLATTS P.J., OMENZ P.A., MARCHANT R., (2015), AFRICLIM: high-resolution climate projections for ecological applications in Africa, Afr J Ecol, 53, 1: 103-108.

POKRYVKOVA J., LACKOOVA L., FUSKA J., TATASOVA L., POLICHT-LATAWIEC A., 2016, Wpływ zanieczyszczenia powietrza na jakość wód opadowych, Rocznik Ochrona Środowiska, 18: 303-321.
Property Rights and Artisanal Diamond Development (PRADD) Pilot Program, United States Agency for International Development, 2008, in: http://pdf.usaid.gov/pdf_docs/ Pnadp019.pdf

SCHEREN P.A., IBE A.C., JANSSEN F.J., LEMMENS A.M., (2002) Environmental pollution in the Gulf of Guinea-a regional approach, Mar Pollut Bull. , 44,7: 633-641.

SÓWKA I., PACHURKA Ł., PRZEPIÓRKA M., ROGULAKOZŁOWSKA W., ZWOŹDZIAK A., (2016), Ocena krótkoterminowego wpływu stężeń pyłu zawieszonego na zdrowie mieszkańców Wrocławia, Rocznik Ochrona Środowiska, 18: 606-615.

SYLLA L., XIONG D., ZHANG H. Y., BANGOURA S. T. (2012). A GIS technology and method to assess environmental problems from land use/cover changes: Conakry, Coyah and Dubreka region case study. The Egyptian Journal of Remote Sensing and Space Science, 15(1), 31-38.

UKWE C. N., IBE C. A. (2010). A regional collaborative approach in transboundary pollution management in the guinea current region of western Africa. Ocean \& Coastal Management, 53(9), 493-506.

UKWE C. N., IBE C. A., NWILO P. C., HUIDOBRO P. A. (2006). Contributing to the WSSD targets on oceans and coasts in west and central Africa: The Guinea current large marine ecosystem project. International Journal of Oceans and Oceanography, (1), 21-44.

WEINSTEIN J.P., HEDGES S.R., KIMBROUGH S., (2010) Characterization and aerosol mass balance of $\mathrm{PM}_{2.5}$ and $\mathrm{PM}_{10}$ collected in Conakry, Guinea during the 2004 Harmattan period, Chemosphere, 78: 980-988.

WHO Global Urban Ambient Air Pollution Database, in: http:// www.who.int/phe/health_topics/outdoorair/databases/cities/ en/

Corruption Perceptions Index 2016, in: https://www.transparency. org/news/feature/corruption_perceptions_index_2016

XU D., BINYET E., (2017), Understanding household energy use, decision making and behaviour in Guinea-Conakry by applying behavioural economics. Renewable and Sustainable Energy Reviews, 79, 1380-1391.

ZHANG X. Y., ZUO Q. T., (2017) Analysis of series variational characteristics and causes of Tarim River Basin runoff under the changing environment, Applied Ecology and Environmental Research, 15, 3: 823-836. 